\title{
ORDEM SOCIAL, POLÍCIA CIVIL E JUSTIÇA CRIMINAL NA CIDADE DE SÃO PAULO (1889-1930)
}

\author{
Luís Antônio Francisco de Souza \\ Professor assistente doutor. \\ Universidade Estadual Paulista Júlio de Mesquisa Filho, Unesp, campus de Marília.
}

\begin{abstract}
Resumo
O presente artigo retoma a discussão sobre o papel da polícia na reforma institucional iniciada na Primeira República, em São Paulo. O argumento central diz respeito à formação das instituições judiciais brasileiras, à continuidade do debate sobre políticas públicas e administração da justiça, bem como o papel da polícia no processo de criminalização das classes populares. No período, a administração da justiça sofreu várias reformas que, aos poucos, permitiram mais espaço para a ação das instituições policiais. A área criminal, de forma constante, continuou a ser cooptada pelos interesses neopatrimoniais dos setores tradicionais da política, permitindo com isso a permanência de práticas inquisitoriais no interior do sistema.
\end{abstract}

\section{Pallavras-chave}

ordem social • polícia $•$ reforma policial $•$ justiça criminal $\bullet$ Primeira República.

\section{Abstract}

The article aims to review the discussion on police role within institutional reform in São Paulo First Republic implementation. The main argument refers to the formation of brazilian judicial system and to the continuity of the debate on public policies reforms, administration of justice and police control over lower social classes, by means of a criminalization of the poverty. The judicial administration was reformed, but that opened space for police institutions to act without constraints. Despite theses changes, state institutions were also used by tradicional social elites in neo-patrimonial ways, allowing the maintenance of unlawful practices within the system.

\section{Keywords}

social order $\bullet$ police $\bullet$ police reform $\bullet$ criminal justice $\bullet$ First Republic. 


\section{Introdução}

No Brasil, a discussão em torno da relação entre ordem social, polícia e justiça criminal ainda se encontra em sua fase inicial. Nos últimos anos, as pesquisas têm dado ênfase à violência e à ineficiência das instituições policiais, mas já se percebe uma mudança deste interesse na direção de uma compreensão mais equilibrada do complexo papel das instituições públicas na formação da ordem social. As pesquisas também contribuem para aumentar a compreensão das relações entre polícia e ordem política, considerando sempre que a polícia é um braço armado do Estado e, nesse sentido, desempenhou papel no controle das dissidências políticas, sobretudo durante os períodos de exceção na história do Brasil. ${ }^{1}$ Um dos resultados das pesquisas sinaliza para a persistência da violência policial, mas ainda estamos longe de compreender os meandros desse problema, sobretudo após mais de 20 anos de uma nova ordem constitucional no Brasil.

Os fatos cotidianos indicam uma preocupante aceitação da violência policial, como mecanismo de gestão da criminalidade e dos criminosos, por parte da população, da mídia e de determinados setores da sociedade brasileira. Os chamados delinquentes são comumente construídos no imaginário social como pessoas que não merecem receber tratamento baseado nos preceitos básicos da justiça ou dos direitos fundamentais. A redução da condição social e jurídica do criminoso, ou dos suspeitos - sua virtual transformação em bandido -, é contraface da legitimação da repressão violenta, da tortura e da morte, cenas repetidas no cenário social brasileiro.

As pesquisas demonstram uma evidente ambivalência no tratamento dispensado pela polícia aos criminosos e moradores das comunidades periféricas, de um lado, e aos moradores dos bairros de classe média ou média alta, de outro. Apesar da igualdade jurídica, a polícia facilmente orienta sua ação com base em dois pesos e duas medidas e, nesse sentido, os policiais desfrutam de uma ampla gama de liberdade na tomada de decisões, liberdade essa que os juristas dificilmente admitem ou questionam. Haveria, nas decisões da polícia, uma contradição entre aplicar a lei e manter a ordem? O propósito do presente artigo é discutir, com base numa revisão da produção das ciências sociais e da

\footnotetext{
1 As pesquisas realizadas por Boris Fausto (1977) e Elizabeth Cancelli (1994) demonstram como, em dois períodos distintos, a polícia foi utilizada pelo poder político e econômico para reprimir oposições políticas, para manter a disciplina fabril pelo controle dos trabalhadores nas fábricas e pela vigilância das organizações sindicais e greves.
} 
historiografia, o processo de construção do poder de polícia no Brasil, durante a Primeira República, e ressaltar as particularidades e as persistências das práticas policiais que oscilam entre a legalidade e a extralegalidade. ${ }^{2}$

\section{A polícia na historiografia, vigilância ou repressão}

A pesquisa realizada no Brasil, nos últimos 20 anos, revela a persistência do corporativismo e de inúmeros problemas no interior das intituições policiais. Mais especificamente, pode-se observar que, no processo de instauração da República, a partir de 1889, práticas relativamente elaboradas de controle da criminalidade urbana foram implementadas, sobretudo no Rio de Janeiro e em São Paulo. As instituições policiais, no período, passaram a sofrer várias reformas que procuravam garantir a ordem social num contexto social em que houve a valorização das liberdades políticas e do mercado de trabalho livre. Nesse período, vários comportamentos urbanos, como a mendicância, a vadiagem, a embriaguez, as desordens, bem como as atividades econômicas autossuficientes, passaram a ser reguladas por uma polícia urbana uniformizada e racionalmente distribuída pelas áreas das cidades. A reorganização da polícia seguiu o modelo da profissionalização, militarização e especialização, com a introdução de técnicas criminalísticas internacionalmente reconhecidas. A polícia, em um curto período de tempo, tornou-se atividade de especialistas, que envolvia, entre outras coisas, a identificação criminal, o controle de prontuários, as técnicas de investigação, perícias e exames de corpo de delito. ${ }^{3}$ A estrutura e o perfil dessas mudanças ainda estão presentes na configuração atual das polícias no país. ${ }^{4}$

2 Este mesmo argumento com outros desenvolvimentos aparece em dois artigos anteriores de minha produção: Polícia, poder de polícia e criminalidade numa perspectiva histórica. In: KOERNER, Andrei (org.). História da justiça penal no Brasil. Pesquisas e análises. São Paulo: Ibccrim, 2006, p. 59-82 e Polícia, violência e patrimonialismo em São Paulo (1889-1930). In: Métis. História \& Cultura. Revista de História da Universidade de Caxias do Sul, v. 6, n. 11, jan/jun 2007, p. 69-92.

3 "O que torna a presença policial, o controle policial tolerável pela população senão o medo do delinquente? (...) Esta instituição tão recente e tão pesada que é a polícia não se justifica senão por isto. Aceitamos entre nós esta gente de uniforme, armada enquanto nós não temos o direito de o estar, que nos pede documentos, que vem rondar nossas portas. Como isso seria aceitável se não houvesse os delinquentes? Ou se não houvesse, todos os dias, nos jornais, artigos onde se conta o quão numerosos e perigosos são os delinquentes?” FOUCAULT, Michel. Sobre a prisão. In: Microfísica do poder. Rio de Janeiro: Graal, 1985, p. 137-138.

4 Segundo o relato de Joseph Love (1982: 175-178), “A Força Pública provia o apoio material ao governo do estado. O processo de profissionalização teve inicio em 1901, quando a designação de Força Pública foi adotada. As mudanças mais importantes, no entanto, ocorreram em 1906, quando Tibiriçá decidiu providenciar a vinda de uma missão militar estrangeira, tendo sido então 
Evidentemente, a modernização e a estatização dos corpos e estruturas policiais integram um processo mais amplo de racionalização da administração governamental. Já no início do século XIX, na Europa, a gestão urbana tornarase grande problema estatal e político e uma forte intervenção nas cidades fez parte do currículo dos empreendedores urbanos. No Brasil, ressalvados os tempos locais, após a Primeira República, a formalização da autoridade e dos poderes legais do Estado espraiou-se pelas mais diferentes áreas de atuação pública. As maiores intervenções resultantes desse processo foram observadas nas políticas agroexportadoras, na higienização urbana, na extensão das malhas ferroviárias, na implantação de portos modernos para escoamento da produção, na reforma urbana e da administração pública. Dentro desse quadro, a justiça e as instituições policiais foram renovadas. As polícias tiveram uma maior especificação legal e uma ampliação das suas funções, autorizadas pelas técnicas e pelos princípios assimilados através da experiência britânica da polícia preventiva. Entretanto, os relatos sobre as resistências à modernização e sobre a persistência dos usos e costumes tradicionais saltam aos olhos. No Brasil, as práticas tradicionais de polícia puderam, de certo modo, conviver com as mais recentes aquisições científicas. Policiais especializados, profissionalizados e com proventos garantidos atuavam lado a lado com policiais leigos, indicados pelas situações políticas e que não podiam contar com salários regulares. A tese que o presente artigo defende diz respeito, portanto, ao fundamento contraditório das práticas policiais: estas baseavam-se tanto na hierarquia policial e numa

muito criticado. (...) Em termos políticos, as reformas promovidas por Tibiriçá, em 1905-06, na polícia civil e no judiciário, atingiram mais diretamente apenas o grupo dos coronéis. Pelo antigo sistema, somente recebiam salários o chefe de polícia estadual e um pequeno número de funcionários superiores, todos sediados na capital, em Santos e em Campinas. As autoridades distritais, ou delegados, bem como os subdelegados, apesar de nominalmente se acharem sob o controle do chefe de polícia, atuavam como servidores honorários, o que os tornava financeiramente dependentes do coronel local. Com Tibiriçá, São Paulo foi o primeiro estado a criar uma estrutura de carreira na polícia civil. Segundo a nova organização, delegados e subdelegados passaram a ser funcionários públicos de tempo integral. Estabeleceu-se o sistema da promoção regular e da rotação de funções. Nos municípios mais populosos, passou-se a exigir que os delegados fossem advogados formados”. Heloísa Fernandes refere-se a essa reforma da seguinte maneira: "Pela reforma, o controle da polícia civil passa diretamente para a esfera estadual, transferindo-se para o presidente do estado o direito de nomeação e de demissão, além do secretário de justiça e chefe de polícia, também dos delegados, subdelegados e suplentes. A reforma converte as atividades do policial civil numa carreira, estipulando uma graduação hierárquica com critérios para nomeação e ascensão. A carreira de delegado fica limitada apenas aos bacharéis de direito e a ascensão é gradual” (1974, p. 149). 
persistente tradição jurídica inquisitorial, quanto nos novos preceitos de uma polícia científica e legalista. ${ }^{5}$

A pesquisa sobre polícia no Brasil, nos últimos 20 anos, promove uma importante revisão em relação ao papel da polícia como braço armado do Estado, das oligarquias rurais e das elites urbanas. As práticas repressivas do Estado contra a classe operária aparecem como traços dominantes na historiografia e, em grande parte, não precisam sofrer revisão. Contudo, as pesquisas têm dado uma importância relativamente menor aos condicionantes de classe social para a compreensão da atuação policial. As instituições de repressão e controle inseriram-se no contexto de formação do mercado de trabalho livre e, nesse sentido, as greves, a organização sindical e os operários em movimento representaram, para as estruturas do poder político, problema de ordem pública. A pesquisa mostra que a classe trabalhadora sempre foi assimilada ao espírito de revolta, ao crime e à desordem. Entretanto, aos poucos, a pesquisa indica que o crime, os criminosos e as questões sociais passaram a ser objeto de ações diferenciadas, que oscilavam entre a assimilação a partir da legislação trabalhista ou repressão a partir da legislação penal. ${ }^{6}$

5 A preocupação das elites brasileiras em colocar o problema da manutenção da ordem em primeiro lugar, mesmo diante do descumprimento da lei, foi notada e analisada por muitos estudos. Num âmbito mais restrito, o problema residiria na orientação diversa que tem o direito penal, que segue os preceitos do direito clássico do Nullum crimen, nulla poena sine lege, e as práticas policiais, que seguem representações do "manual” lombrosiano de criminologia. Cf. QUEIROLO, Sylvia. O espaço conceitual da periculosidade. Direito penal e criminologia. Tese de Mestrado, 1984; FRY, Peter e CARRARA, Sérgio. As vicissitudes do liberalismo no direito penal brasileiro. Revista de Ciências Sociais. 2 (1), 1986; ALVAREZ, Marcos César. Apontamentos para uma história da criminologia no Brasil. In: KOERNER, Andrei (org.). História da justiça penal no Brasil. Pesquisas e análises. São Paulo: Ibccrim, 2006.

${ }^{6}$ A pesquisa sobre polícia no Brasil tem avançado muito, dando mostra do grande interesse dos pesquisadores sobre os problemas da construção da ordem social na sociedade brasileira. Recomendo, entre outras, as seguintes obras: HOLLOWAY, Thomas H. Polícia no Rio de Janeiro. Repressão e resistência numa cidade do século XIX. Rio de Janeiro: FGV, 1997; ROSEMBERG, André. Ordem e burla. Processos sociais, escravidão e justiça em Santos. São Paulo: Alameda, 2006; SALLA, Fernando. As prisões em São Paulo, 1822-1940. São Paulo: Annablume, 1999; MAUCH, Cláudia. Ordem pública e moralidade. Imprensa e policiamento urbano em Porto Alegre na década de 1890. Santa Cruz do Sul: Edunisc, 2004; BRETAS, Marcos Luiz. A guerra das ruas. Povo e polícia na cidade do Rio de Janeiro. Rio de Janeiro: Arquivo Nacional, 1997; BRETAS, Marcos Luiz. Ordem na cidade. O exercício cotidiano da autoridade policial no Rio de Janeiro. Rio de Janeiro: Rocco, 1997; VELLASCO, Ivan de Andrade. As seduções da ordem. Violência, criminalidade e administração da justiça. Minas Gerais, século XIX. São Paulo: Edusc, 2004; ROSEMBERG, André. Polícia, policiamento e o policial na Província de São Paulo no final do Império. Tese de Doutorado, FFLCH-USP, 2008. 
Mais ainda, a pesquisa demonstra que a polícia foi um instrumento de mediação (muitas vezes violenta) dos conflitos urbanos surgidos no bojo do processo de industrialização e de exploração do trabalho assalariado. Dentre as ações policiais, a que mais se destacou foi a repressão aberta às greves, às organizações sindicais e à imprensa operária. Mas um controle mais sutil foi sendo implementado na regulação do mercado de trabalho industrial e na sociabilidade permitida no espaço urbano. Eram parte das atividades policiais a fiscalização de bares, bordéis, agremiações sindicais e políticas, bem como a manutenção de listas e prontuários de criminosos, presos, grevistas, prostitutas e usuários de hotéis. A polícia firmou convênios com alguns industriais para fazer a identificação de trabalhadores e, assim, depurar a classe operária dos elementos perigosos: criminosos e anarquistas. A instituição policial também fez a gestão social urbana ao encaminhar indivíduos não engajados no mercado de trabalho (mendigos, ébrios, loucos e menores) às diversas instituições de reclusão ou de assistência, criadas na Primeira República. A polícia regulamentou os costumes dos trabalhadores imigrantes e controlou o cotidiano urbano, fazendo observar a legislação da época. A instituição também teve papel na criminalização da delinquência urbana e auxiliou no processo de institucionalização da loucura, da menoridade, da mendicância e da prostituição.

Por outro lado, o processo de formação da autoridade estatal não foi tarefa simples. Problemas ligados à corrupção e às arbitrariedades de policiais surgiram e refletiram também, sem dúvida, as deficiências institucionais: falta de recursos, de profissionalismo e de controle interno. A atuação policial foi marcada por conflitos de interesses em que, no bojo da constituição da ordem social republicana, a proteção da propriedade e de interesses privados confundia-se com a manutenção da ordem social. Esta era uma polícia que foi objeto de manipulação política, sendo usada como mecanismo de gestão privada de conflitos. O quadro complexo que emerge da pesquisa sinaliza, no interior do aparato policial, a constituição de uma subcultura policial descompassada, oscilando entre repressão e disciplina, entre lei e ordem. ${ }^{7}$

\footnotetext{
Antonio Luiz Paixão sustenta que há uma nítida oposição entre lei e ordem na sociedade brasileira, sendo a "Legalidade para as 'pessoas civilizadas' e ordem para os 'marginais': esta parece ser a lógica institucional que produz o controle social no Brasil.” Controle esse ajustado por uma cultura jurídica que define diferentes classes de cidadania. PAIXÃO, Antonio Luiz. Crime, controle social e consolidação da democracia. In: REIS, Fábio Wanderley. \& O'DONNELL, Guillermo. A democracia no Brasil. Dilemas e perspectivas. São Paulo: Vértice, 1988, p. 179 e 191. Embora o autor estivesse fazendo referência ao contexto da redemocratização do Brasil, em meados dos anos 1980, a pesquisa histórica mostrou esses mesmos dilemas na sociedade brasielira da Primeira República (Souza, 2006; Alvarez, 2006; Koerner, 1998; Rosemberg, 2006).
} 


\section{Polícia no Brasil, entre mudança e continuidade}

A República representou uma mudança de estatuto jurídico em relação à Monarquia, mas não imprimiu uma ruptura profunda na estrutura social brasileira. A longa tradição escravista mais o relativo isolamento das fazendas de café proporcionaram o surgimento de relações costumeiras de modo a ressaltar o poder real depositado na figura do fazendeiro. A República, embora tenha criado ou ampliado mecanismos estatais de controle sobre as situações locais, dependia politicamente das oligarquias e uma ampla ética de arranjos privados para os conflitos se espraiou pelas estruturas burocráticas. Mesmo no contexto alterado pela ascenção das fazendas do oeste paulista, os principais cargos da administração pública foram apropriados por grupos de interesse e as elites republicanas distribuíram cargos para seus correligionários. As oligarquias puderam ingressar na política e apoiar representantes diretos ou indiretos de seus interesses, criando na política republicana um liberalismo descompassado. As elites econômicas pugnaram por relações econômicas liberais mas eram ciosas do papel que o Estado deveria ter na manutenção de seus interesses sociais. No âmbito privado, o patriarcalismo e as estratégias de exceção vicejaram livremente. Nas fazendas mais modernas, práticas avançadas de produção e de gestão econômica conviveram com a exploração do trabalho em regime de semiescravidão dos antigos escravos, de agregados brancos e de colonos imigrantes. As cidades fervilhavam. Ondas de imigrantes chegaram em busca do eldorado. A desordem parecia residir em todos os becos e esquinas e, com ela, as doenças e as ameças de revolta. Rapidamente, as cidades foram urbanizadas e a população dos operários foi transferida para as periferias, os cortiços foram sendo derrubados e o centro urbano tornou-se lugar sanitarizado. Palacetes, edifícios públicos em estilo republicano, um novo padrão de monumentalidade nas construções marcaram a autoimagem dessas elites que nasceram e cresceram ao derredor dos pelouros e dos troncos das fazendas. Modernidade, para as novas-velhas elites fabris-urbanas, significava ordem, saneamento, embelazamento, controle policial estrito e respeito às hierarquias sociais. À noite, os cabarés e os lupanares, protegidos dos olhares indesejáveis pela iluminação tremeluzente das lamparinas recém instaladas, eram frequentados por grande número de homens. No mundo urbano, o mercado de trabalho livre, com suas oscilações, sofreu as sanções dos códigos de posturas municipais e dos regulamentos policiais. A cidade cresceu segmentada e assim permaneceu nas décadas seguintes. ${ }^{8}$

8 A historiografia é detalhada e meticulosa em relação às vicissitudes da República no trato com os 
O poder discricionário da polícia andou de par com a ascensão das oligarquias e de seus representantes na burocracia do partido e da administração pública. O republicanismo liberal da Primeira República não colocou em campos opostos o discurso do interesse público, da honestidade, da lisura de ações e intenções, da preocupação com a nação e as práticas patriarcais e atrabiliárias. O Estado republicano representou assim o compromisso com a sustentação política e institucional dos potentados locais e com a expansão do empreendimento agroexportador: modernização sem modernidade, nos dizeres de Raymundo Faoro. A Primeira República, portanto, conciliou a racionalidade jurídica e as estratégias políticas patriarcais e paternalistas. O coronelismo penetrou profundamente na estrutura do Estado, nas almas e mentes dos mais diferentes atores sociais e políticos. O princípio federativo, a legalidade e a rotatividade na ocupação de cargos eletivos não foram suficientes para romper com o legado do compromisso historicamente contruído no país entre poder público e interesses privados. ${ }^{9}$

A aceleração da urbanização e da industrialização não representou obstáculo à privatização do poder público. As reformas institucionais implementadas na República puderam conviver pacificamente com o ethos de dois pesos e duas medidas. As indústrias modernizaram a estrutura do país. As oligarquias trouxeram as últimas novidades da civilização europeia, incluindo modas, costumes, letras e ciência. Mas as relações fabris eram terríveis. O tratamento de presos e suspeitos estava aquém de qualquer consideração humanitária. Os momentos em que emergiram fagulhas de uma consciência social do proletariado resultaram no incremento da repressão e do controle institucional sobre o cotidiano. A República nasceu sob o impacto da liberdade civil, política e jurídica, mas era constrangida materialmente pelo peso de condições sociais e de tratamento desiguais. A modernização dos aparelhos de punição e repressão do crime, nor-

grupos sociais urbanos que pugnavam por direitos, por justiça e por melhores condições de trabalho (Cf. Carone, 1973; Fausto, 1984; Rago, 1985; Chalhoub, 1986; Carvalho, 1991, Pinto, 1994).

9 Embora haja divergências e matizes entre os autores, o conceito de uma ordem social e política baseada na apropriação privada da esfera pública é uma das interepretações mais persistentes da história brasileira (cf. Leal, 1975; Faoro, 1989; Franco, 1983; Carvalho, 1981; Abreu, 1988). Nessa direção, por exemplo, afirma-se que a "administração pública é vista como um bem em si mesmo, e a organização governamental tem as características de um patrimônio a ser explorado, e não de uma estrutura funcional a ser acionada para obtenção de fins heterônomos". SCHWARTZMAN, Simon. São Paulo e o Estado nacional. São Paulo: Difel, 1975, p. 21. Ou ainda que “a dominação pessoal tranforma aquele que a sofre numa 'criatura domesticada': proteção e benevolência the são concedidas em troca de fidelidade e serviços reflexos” (Faoro, 1989, p. 634). 
malização da loucura, institucionalização da mendicância e delinquência foram consideradas paralelas aos sucessos das fazendas e da economia fabril. ${ }^{10}$

Esse quadro não deixa dúvidas, as reformas republicanas foram em grande parte meramente nominais. Os fundamentos de sociedade hierárquica não se transformaram. Por exemplo, o processo criminal brasileiro reatualizou a tradição inquisitorial presente na ação do Santo Ofício e no Livro V das Ordenações Filipinas. Segundo esta tradição, as autoridades policiais detinham controle sobre o inquérito policial e exerciam considerável poder discricionário sobre o suspeito e sobre as diligências invetigatórias. O inquérito policial não só forneceu elementos para a denúncia como também prefigurou a culpabilidade do indivíduo. O indivíduo, sob a ótica da polícia, permaneceu em estado de suspeição e, assim, teve a obrigação de provar sua inocência diante das autoridades inquisitoriais. Mesmo que a nossa tradição jurídica afirme que o inquérito policial não tem valor condenatório, a prática revela exatamente outra realidade. Delegados e investigadores indignavam-se com a exclusividade do Judiciário diante da pronúncia e do julgamento. Havia uma zona de intenso conflito entre a polícia e o Judiciário, na medida em que, para a polícia, a elucidação da verdade sobre as ocorrências criminais era responsabilidade dos policiais; o juiz trabalhava sobre o material dessas investigações e podia no máximo reinquirir testemunhas, mas não podia refazer provas materiais. A polícia passou a desenvolver atitudes antagônicas às prescrições legais, pois imaginava que os juízes usurpariam seu poder. A ação policial off records, os acertos, a violência e o domínio exclusivo sobre o inquérito, além, é claro, dos desmandos, contribuíram para a constituição de uma subcultura policial de extralegalidade, baseada numa grande dose de arrivismo social, de grande paranoia e de desprezo pela legalidade. Essas disposições foram importantes complicadores da busca pela justiça e ajudaram a manter o rebaixamento da população à condição de subcidadania. ${ }^{11}$

\footnotetext{
${ }^{10}$ Pelo menos é o que se pode entrever pela pesquisa realizada em torno do cotidiano dos trabalhadores pobres na cidade de São Paulo, na política de implantação de instituições asilares, na criação da Penitenciária do Estado de São Paulo e nas diversas reformas policiais (Rago, 1985; Cunha, 1986; Pinto, 1994; Salla, 1999; Alvarez, 2003; Souza, 2006).

11 “Quando previne a criminalidade, a polícia atua sobre o comportamento virtual dos indivíduos e grupos, usando de arbítrio para prevenir aquilo que considera um estado potencial de quebra da ordem jurídica. Julga, então, indivíduos prevendo seu comportamento futuro - seu grau de periculosidade. Age, portanto, dentro dos princípios da escola positiva de Direito Penal. Tal ambiguidade de princípios e funções faz com que a polícia, não-oficialmente, adjudique e puna criminosos (...) utilizando outros procedimentos e subordinando suas atividades a 'princípios puramente' inquisitoriais, diferentes daqueles do judiciário”. LIMA, Roberto Kant de. Cultura jurídica e práti-
} 
A gradual distinção das funções judiciárias e administrativas da polícia não parece ter representado maior garantia dos direitos civis e políticos das populações urbanas; ao contrário, aumentou a tensão existente entre as estruturas burocráticas e a manipulação da administração em favor de interesses particulares. A reestruturação da polícia nas capitais não reduziu o grau de discricionariedade comum às ações policiais. Os juristas postulavam a reserva legal do poder de polícia, segundo o qual, os limites da atuação policial não estariam irrestritamente prescritos no direito; ao contrário, a polícia deveria ter poder para decidir a modalidade de ação repressiva ou preventiva a ser utilizada diante dos problemas apresentados. As medidas jurídicas, como as penas previstas pelo Código Penal, foram apenas uma parte de um repertório mais amplo de ações da polícia. As medidas para-jurídicas e regulamentares, expressas em medidas administrativas como a prisão para averiguações, termos de segurança e de tomar ocupação, controle de manifestações públicas, fiscalização de agremiações sindicais e políticas foram usadas exclusivamente pela polícia na defesa do Estado e da ordem pública. ${ }^{12}$

Em outros termos, como exigir da instituição policial uma atitude de respeito à cidadania nessas condições? Não é por menos que similar ao período da escravidão, as vítimas da violência massiva das violações de direitos humanos e do descaso social transmutavam-se em algozes quando tinham à sua disposição armas e um mínimo de organização. Nesse sentido, é claro que o lugar institucional de onde parte o discurso da ordem e da lei emana mais poder que qualquer outro. As polícias movimentaram um amplo esquema utilitário de segregação que sustenta as nossas profundas desigualdades econômicas e sociais. Nesse sentido, elas eram parte de um todo e, como tal, apresentavam contradições de difícil superação. ${ }^{13}$

cas policiais: a tradição inquisitorial. Revista Brasileira de Ciências Sociais, 10 (04), 1989, p. 71.

${ }^{12}$ A leitura mais recorrente sobre esse processo aponta para o paralelismo entre o fortalecimento do estado no interior da política nacional e o reforço às instituições que sustentavam política, social e criminalmente esse fortalecimento (cf. Lovre, 1982; Fernandes, 1974; Faoro, 1989). Na memorialística policial do período, ocorria uma leitura mais direta da importância da polícia na manutenção da ordem social republicana: “A polícia tem o dever de restringir a liberdade. (...) uma Lei de Segurança Pública viria elevar o nível da ação moralizadora da polícia.” FRANCESCO, Braz di. Pela cultura policial. São Paulo: Casa Duprat, 1931, p. 17.

${ }^{13}$ Essa situação é interessante porque exige do intérprete uma postura dubidativa em que coloca tanto as estratégias institucionais de controle das populações urbanas, por meio de mecanismos disciplinares e de um saber especializado que investe sobre os corpos dos indivíduos, como também as formas múltiplas de resistência social e política por parte das classes submetidas aos desmandos e ao controle (cf. Foucault, 1987; Thompson, 1993). 


\section{Interfaces entre polícia e justiça criminal}

A organização da administração da justiça de São Paulo, durante a Primeira República, também demonstra o espaço ocupado pelo poder de polícia. A Lei $n^{\circ}$ 80, de 25 de agosto de 1892, promoveu uma grande reforma judiciária na medida em que a República entendia a magistratura como espinha dorsal do edifício jurídico-político do novo regime. A comarca da capital ficou dividida em 18 distritos, com seus respectivos juízes de paz, e cinco varas criminais, com seus cinco respectivos juízes de direito. O número de varas somente aumentou novamente nos anos 1920, passando a um total de nove. No resto do Estado, a reforma extinguiu os antigos termos e, simultaneamente, 29 comarcas foram criadas, perfazendo em todo o Estado um total de 95 comarcas. Mas, depois dessa data, poucas mudanças ocorreram, até pelo menos 1921, a despeito do acentuado crescimento populacional. Na comarca da capital, havia um tribunal do júri com jurisdição na própria comarca e o Tribunal de Justiça com jurisdição em todo o território do Estado, composto por nove ministros, nomeados pelo presidente do Estado, com a aprovação do Senado, dentre os juízes de direito mais antigos em exercício no Estado. O tribunal julgava em última instância os recursos e apelações das ações legais dos juízes de direito; as apelações interpostas às sentenças do júri; concedia habeas-corpus; e exercia controle interno da administração da justiça em relação às responsabilidades de seus membros. O presidente do Tribunal de Justiça era escolhido pelo presidente do Estado dentre os demais ministros. Dos ministros do tribunal, em sua fase anterior, quando ainda era denominado de Relação, metade havia ocupado o cargo de chefe de polícia e o cargo no tribunal constituía um momento de grande influência, do juiz e de sua família, no cenário político do período. Com a República, uma nova estrutura foi montada, sendo que os ministros empossados não tinham relações com a antigo tribunal. Em São Paulo, entre 1892 e 1910, com exceção de cinco ministros, todos os demais tinham algum vínculo com as regiões plantadoras de café, como a Mogiana e o vale do Paraíba. A extinção do sistema de entrâncias permitia a um juiz permanecer por muitos anos em uma comarca até a aposentadoria; caso fosse promovido ao tribunal por antiguidade, esse mesmo juiz permanecia aí por um longo período, mas após os 65 anos quando se dava a aposentadoria compulsória.

O Tribunal do Júri compunha-se dos juízes de fato, isto é, os jurados, presididos pelo juiz de direito, anualmente designado pelo Tribunal de Justiça. Os juízes de fato eram aqueles cidadãos eleitores, considerados pelo bom senso e integri- 
dade de caráter. O serviço do júri era obrigatório. Os jurados deviam ter meios pecuniários próprios para suportar os encargos que o serviço acarretasse. Não podiam servir no júri os indivíduos que fossem pronunciados, tivessem assinado termos cominatórios ou tivessem sido condenados por sentença definitiva nos seguintes crimes: furto, roubo, bancarrota, estelionato, falsidade ou moeda falsa. Praças de pré e os criados de servir também não deviam se alistar como jurados. Enquanto durasse seu exercício, não podiam servir como jurados, o presidente do Estado, os membros do Poder Legislativo, os juízes, os professores primários, os representantes do Ministério Público e os militares em serviço ativo. Aqueles que já tivessem servido em uma sessão do ano em vigor e os maiores de 65 anos podiam ser dispensados do júri. Reforma subsequente passou a permitir sorteio de jurados dentre os funcionários, letrados, profissionais liberais e profissões técnicas, o que, segundo Afrânio Peixoto, elevou o "nível moral” do júri. ${ }^{14}$

No início da República, a instituição do júri ocupava-se do julgamento de todos os crimes cuja pena excedesse seis meses de prisão celular. Mas, as críticas provenientes do meio jurídico e, principalmente, dos meios policiais provocaram constantes restrições ao júri. Um delegado de São Paulo afirmou que o quadro de impunidade existente no Estado decorria da

Fraqueza da repressão, a tolerância dos juízes e a liberdade dos costumes jurídicos, que criaram uma situação aflitiva para a sociedade honesta que tem a vida, a honra e a propriedade de seus membros sem garantias eficazes, ameaçadas por todos os maus instintos, destruídos impunemente pelo punhal, pelo veneno, pelo fogo, pela prepotência (Francesco, 1931, p. 69).

Para esse delegado e, por extensão, para a polícia, todo o sistema que visava garantir os direitos dos criminosos e dos presos era visto como um privilégio desnecessário. Daí também o mesmo autor afirmar serem ineficazes tanto a pena de prisão celular quanto o policiamento convencional. Deixar de "aprisionar a polícia em fórmulas rígidas” era a única forma de salvar a sociedade contra

\footnotetext{
${ }^{14}$ Juristas e criminologistas defendiam com afinco a redução da atuação do júri popular aos crimes de homicídio, pois concebiam que os jurados leigos não tinham condições de cumprir seus papéis numa época em que a ciência poderia dar novos contributos à compreensão do crime e do criminoso, bem como oferecer recursos para a atividade preventiva das instituições policiais. Afrânio Peixoto, importante alto funcionário policial e especialista em criminologia, era um desses críticos (cf. Peixoto, 1933, p. 259).
} 
os ataques dissolventes dos criminosos. A partir de 1925, o júri passou a julgar somente os crimes relativos a homicídios dolosos consumados ou tentados. ${ }^{15}$

A Lei $n^{\circ} 80$, ao extinguir os antigos termos judiciários e constituir cada um deles comarca distinta, elevou à categoria de comarca inúmeras cidades, ou circunscrições completamente destituídas de rendas ou de sede para instalar o Tribunal do Júri. Essas cidades também não possuíam funcionários competentes ou outras condições técnico-burocráticas essenciais para que a administração da justiça pudesse se processar livremente. A reforma também suprimiu os cargos de juízes de paz adjuntos e os tribunais correcionais. Ao fazer isso, simplificou a hierarquia da administração da justiça e reduziu o número de magistrados. ${ }^{16}$ O cargo de juiz de paz continuava sendo provido por eleição e podiam se candidatar a ele os cidadãos, maiores de 21 anos, que residissem há mais de dois anos no respectivo distrito. Havia eleição para juiz de paz a cada três anos, sendo três juízes eleitos, cada um devendo servir por um ano. Os juízes de paz, pelo regulamento de 1892, na parte criminal, ainda mantinham atribuições policiais tais como: a) processar e julgar as infrações de posturas municipais; b) conceder fianças provisórias; c) proceder corpo de delito; d) obrigar a assinar termos cominatórios; e) prender os criminosos e deter os turbulentos e bêbados.

O cargo de juiz de direito era de nomeação do presidente do Estado. Para estar habilitado à nomeação, o candidato devia ser a) bacharel em direito; b) ter tido, pelo menos, três anos de efetivo exercício da advocacia, como juiz de paz, no Ministério Público ou nos extintos cargos de juiz municipal e juiz substituto; c) ter passado por concurso. Essa última exigência foi abolida pela Lei ${ }^{\circ}$ 1.084, de 14/09/1907, aumentando o poder da Secretaria da Justiça e Segurança Pública sobre o Judiciário, pois, para habilitar-se ao cargo de juiz de direito, o candidato devia "provar suas qualidades de diplomado em direito" perante a Secretaria. Consequentemente, a justiça dependia de relações patrimoniais com os interesses e desígnios das autoridades do Poder Executivo. Os cargos da magistratura passaram a ser perpétuos e inamovíveis. Aparentemente, essas

\footnotetext{
${ }^{15}$ Boris Fauto (1984, p. 227) relatou essa transformação sem ter explorado todas as suas dimensões, o que evidentemente justifica uma pesquisa específica, começando, por exemplo, nas mudanças no procedimento de registro, seleção e sorteio dos jurados, bem como em seu perfil socioeconômico.

${ }^{16}$ Segundo ex-juiz de direito do período, essa reforma cometeu "assim, outro imperdoável erro, porque os primeiros bacharéis em Direito correspondiam de certa forma ao antigo juiz municipal. (...) e os segundos, constituídos pelo restrito pessoal dotado de certa idoneidade nos termos, se incumbiam do julgamento de delitos de pequeno tomo cujo processo se efetivava com grande proveito social” (Faria, 1942, p. 11).
} 
modificações obrigavam o governo do Estado a tomar outro tipo de medida para “interferir” nos cargos de juiz de direito. É notório o caso em que, sendo o juiz de direito de Ribeirão Preto da oposição e tendo sua atuação sido considerada partidária, o governo procurou criar uma segunda vara para diminuir ou mesmo anular a influência da primeira. ${ }^{17}$ A atribuição básica do juiz de direito, na parte criminal, era formar culpa nos crimes comuns e, cumulativamente, todas as demais atribuições das autoridades judiciárias inferiores e das autoridades policiais, relativas ao inquérito policial. A redução do número de magistrados obrigava a que, em caso de impedimento, o juiz de direito fosse substituído nos julgamentos contenciosos definitivos por um juiz de direito da comarca vizinha, e em outros atos jurídicos, como prisão preventiva, pronúncia e despronúncia, pelos juízes de paz leigos que eram representantes das elites locais. Apesar de tudo isso, o juiz de direito podia ser transferido para outra comarca ou substituído, desde que o Tribunal de Justiça julgasse que sua presença pudesse comprometer determinados interesses na comarca. No Fórum Criminal da rua Riachuelo, funcionaram as varas criminais da comarca da capital. A Lei $\mathrm{n}^{\circ} 1.113$, de 24/12/1907, regulamentada pelo Decreto $\mathrm{n}^{\circ} 1.575$, de 19/02/1908, criou um sistema de distribuição dos processos entre as três varas criminais privativas; a partir deste momento, os processos foram distribuídos conforme o volume de papéis entrados no fórum e, consequentemente, pela primeira vez a escolha do juiz de algum feito criminal tornara-se aleatória.

A situação funcional dos membros do Ministério Público também indicava um estreitamento do poder de intervenção da justiça em questões relativas ao interesse público. Os promotores figuravam como auxiliares das autoridades judiciárias. No Estado de São Paulo, havia um procurador geral, e, na capital, apenas dois promotores públicos. Todos os membros deviam ser formados em Direito. O processo de nomeação do Ministério nunca ficou suficientemente esclarecido, sendo certo, entretanto, que eram nomeados diretamente pelo presidente do Estado. Somente nos anos vinte mais um lugar de promotor foi criado na capital. Mas, considerando que toda a justiça criminal formal da cidade dependia da intervenção dos promotores, é possível imaginar os obstáculos para que a justiça fosse realizada de maneira adequada. Os processos-crimes analisados pela pesquisa indicam que era muito comum encontrar os promo-

${ }^{17}$ Estes são os pontos de vista de Luiz Fonseca, biográfo de Washington Luis durante a campanha deste para a presidência do Estado de São Paulo em 1920 (Fonseca, 1920, p. 40-48). 
tores públicos sobrecarregados de trabalho, o que fazia com que determinadas ações criminais prescrevessem antes mesmo da pronúncia. Outro complicador da situação foram os chamados processos policiais, nos quais o delegado de polícia processava vadios e demais contraventores. As notícias dos jornais da época indicam que, por dia, mais de duzentos vadios podiam ser processados pela polícia; considerando a exigência da presença de um promotor em cada uma das audiências desses processos, imagine-se o montante de trabalho que ele devia analisar. Se a acusação nos processos podia ser prejudicada com o diminuto número de promotores, a defesa dos acusados era ainda mais precária, dependendo, no mais das vezes, da assistência judicária promovida pelos acadêmicos de Direito. Somente na Lei n 1.763, de 29 de dezembro de 1920, é que foi criada a Assistência Judiciária, para auxiliar as pessoas desprovidas de meios pecuniários em suas ações judiciais. Entretanto, seu funcionamento nunca foi suficiente para dar conta das necessidades.

Levando ainda em consideração as reclamações em torno dos baixos salários dos magistrados, as reformas diminuíram a capacidade do sistema de distribuir justiça, ao mesmo tempo que permitiu à política local ter assento em decisões jurídicas. ${ }^{18}$ Porque o juiz de paz, “eleito segundo indicações partidárias, e não raro escolhido entre correligionários de mais fácil manejo, ou de subserviência mais segura, passou a exercer atribuições importantes, confiadas à magistratura togada, e isto com o constante apoio dos dirigentes superiores do Estado, que, durante anos intermináveis para o foro, não quiseram reagir contra semelhante estado de coisas”. ${ }^{19}$ Igualmente, os juízes togados estavam sujeitos aos caprichos dos chefes locais: "Se estes consentiam em satisfazer-lhes os caprichos, a

${ }^{18}$ Esse leitura aponta, portanto, para um efeito paradoxal dessas mudanças. Esse efeito também pode ser observado na comparação com o sistema judiciário do Império, em que foi gestada uma elite judiciária nacional. Na Primeira República, ao contrário, as carreiras judiciais ficaram restritas às unidades federadas, não havendo portanto circulação e integração da elite do Judiciário. Os magistrados permaneceram, durante o período, fortemente atrelados aos poderes locais (cf. Leal, 1975 e Koerner, 1998). Essa leitura vale para a elite paulista como um todo: "Uma análise desagregada de cada geração revela a crescente 'provincialização' da elite paulista, ou seja, a enfase progressiva ao recrutamento dentro do próprio estado e ao treinamento políticos em São Paulo e não em postos fora do estado. (...) Tal tendência foi também confirmada pelo estudo da elite judiciária paulista, definida como o conjunto de todos os membros do Tribunal de Justiça (...) Do Império até a era Vargas, o número de juízes naturais de São Paulo cresceu continuamente, como também o de formados pela Faculdade de Direito do Estado (Love, 1982, p. 224-225).

${ }^{19}$ Esta afirmação do ex-juiz e memorialista do direito merece também corroboração por meio de pesquisa histórica mais detida, mas é certamente uma pista interessante das interveniências políticas do exercício da função judicial (cf. Faria, 1942, p. 12). 
administração da justiça, anarquizada, deixava de inspirar confiança ao povo e, fatalmente, o impelia para as hostes do mandão, no empenho de receber favores administrativos ou judiciários.” Não obstante, os juízes e promotores de justiça entravam em choque com os líderes locais e acabavam sendo objeto de perseguição: "representações pela imprensa, desacatos premeditados nos auditórios da justiça, cartas anônimas repassadas de calúnias e aleivosias, tudo se erguia contra o infeliz magistrado, que não raro sucumbia na luta desigual contra o caciquismo tão inexorável quanto destituído de cultura.” É conhecido o caso da comarca de Ituverava, no qual o chefe político exigia que o promotor público abandonasse seu ofício local. O jovem promotor acorreu à cidade de São Paulo em busca de apoio governamental. O presidente do Estado prometeu prestigiar-lhe o exercício do cargo. De volta à cidade o promotor logo encontrou o chefe político na rua:

- Como, você aqui? Pois não lhe disse já que se retirasse? Há um gesto ameaçador de chicote que se ergue para o golpe ultrajante; soa tiro seguro; um dos homens cai banhado em sangue; família numerosa se vê privada do arrimo paternal; e dias depois, na cadeia, o desgraçado mancebo, que se fizera assassino, cortava a existência, talvez destinada a grandes cometimentos, com outra arma transformada em cruel instrumento de suicídio (Faria, 1942, p. 24-27).

Desde o governo de Jorge Tibiriçá (1904-1908) foram feitas propostas de reforma da magistratura para que a justiça pudesse ser "mais acessível e de execução mais rápida e menos onerosa.” As grandes linhas das reformas visavam a criação de varas privativas; a ampliação da competência dos juízes singulares para que os processos e julgamentos de crimes afiançáveis fossem agilizados e para "diminuir a impunidade resultante do defeituoso funcionamento do júri”; a organização do Ministério Público e revisão dos processos civil e criminal. ${ }^{20}$

${ }^{20}$ É claro que essa é uma interpretação proveniente de um biógrafo fortemente interessado em recuperar a memória dos feitos das principais lideranças republicanas paulistas (cf. Soares Jr., 1958, p. 479-480). Joseph Love, por exemplo, afirma que “O regime republicano introduzido em 1889 provocou importantes modificações nas regras políticas básicas. Uma substancial parte das rendas previamente administradas pelo governo central passou para a alçada local e estadual. Além do mais, aumentou o número de cargos eletivos e o eleitorado expandiu-se consideravelmente. Com a supressão do poder moderador, a substituição ordenada dos grupos exercendo o poder a nível local, estadual e federal passou a constituir um problema que as instituições da Primeira República nunca puderam solucionar de modo adequado.” Nesse sentido, ele discorda de Raymundo Faoro, segundo a qual o poder oligárquico local teria se sobressaído ante o poder central durante a Primeira República. Para aquele "o poder dos senhores rurais foi progressivamente restringido, não pelo governo federal mas pelo estadual, em parte porque as rendas desse último aumentariam mais rapidamente que as da administração central” (Love, 1982, p. 174-175). 
Essas propostas de mudança foram incorporadas ao programa de governo de Washington Luís (1920-1924). Elas foram consubstanciadas na Lei n 1.795 , de 1921, com a criação de juízes substitutos, suprimindo o papel do juiz de paz como substituto do juiz de direito, com a classificação das comarcas em entrâncias e com a supressão das custas, emolumentos e percentagem pagas aos juízes de direito que, então, tiveram seus salários aumentados. A partir dessa reforma, foram criados mais dois lugares de juízes do Tribunal de Justiça, perfazendo um total de 17, foi estabelecido um Conselho Disciplinar de Magistratura e criado o cargo de corregedor geral de justiça dentro da estrutura do tribunal. No entanto, essa reforma ainda não havia eliminado o patrimonialismo embutido no exercício dos cargos da magistratura paulista, pois a limitação do tempo de permanência do juiz no exercício antes de obter promoção facilitou o favoritismo e os arranjos de parentesco. A transferência de magistrados também continuou a ocorrer independentemente dos critérios burocráticos, embora a reforma tenha impossibilitado que as transferências se processassem mediante pagamento de propinas, como era usual no sistema anterior:

A operação se fazia por meio de permuta com volta em dinheiro depositada por acordo comum em mãos fiéis que o entregavam ao beneficiado quando aquela se tornava efetiva; e assim sem oposição do Tribunal ou do governo, se estendia à magistratura negócio muito praticado entre serventuários de justiça, e que toda a gente considerava perfeitamente normal, a despeito dos protestos anódinos de alguns idealistas dominados de civismo talvez ridículo (Faria, 1942, p. 32).

Assim, na Primeira República, os juízes de direito se beneficiaram da diminuição das competências do juiz de paz e do Tribunal do Júri, mas permaneceram fiéis aos poderes e interferências locais muito mais do que os magistrados do Império. A elite judicial dispunha dos cargos públicos de forma patrimonial. A análise do padrão de ocupação dos cargos da magistratura e da polícia revela que muitos representantes da elite acumulavam posições, sendo muitas delas, na letra da lei, consideradas incompatíveis. ${ }^{21}$

${ }^{21}$ De toda forma, o governo de Washington Luis é bem avaliado nessa área, pois "preocupado com a modernização do estado, promoveu uma ampla reforma que profissionalizou o poder judiciário, tornando-o muito menos dependente das autoridades locais. Uma lei aprovada a 17 de novembro de 1921 estabeleceu a exigência de exames para a carreira judiciária, instituiu um sistema de promoção regular e proibiu a substituição do juiz de direito, que devia ser um funcionário estadual com treinamento formal em direito, pelo juiz de paz, em geral dependente do coronel sem nenhum preparo técnico. Não menos importante foi o aumento do salário dos 
A morosidade, a incompetência e o vínculo político eram críticas constantes que a polícia dirigia aos juízes e promotores públicos. Certamente, a aplicação da justiça passou, nas primeiras décadas da Primeira República, por evidente estagnação. Mas, na lei e na prática, as autoridades policiais já haviam se tornado os juízes das misérias alheias, como bem notou um memorialista. ${ }^{22}$ Mais ainda porque, em verdade, cabia à polícia estadual, mais do que à magistratura, exercer a autoridade governamental diante das situações locais dissidentes, sobretudo em momentos de eleições nos municípios, conforme relatava o chefe de polícia, Antônio de Godoy:

Na grande maioria das localidades do Estado, a ordem pública, salvo pequenas occorrências sem gravidade, não deixou de ser mantida. Bem sciente da suprema obrigação da polícia, procurei sempre, com tenaz esforço, velar por ella em todo o território do Estado, empregando todos os meios ao meu alcance para evitar e reprimir quaesquer perturbações. Em minhas conferências diárias com as autoridades da Capital e na volumosa e quotidiana correspondência com as das outras localidades, tudo fiz, pelo conselho, pela recommendação, e pelo accordo, no sentido de cohibir os abusos prejudiciaes à ordem e tranquilidade. Sempre que as ocorrências se revestiam de alguma gravidade, ou havia occasião para prováveis distúrbios e conflictos (como durante as grandes festas públicas e ajuntamentos de qualquer carácter), avoquei a mim a superintendência do serviço de vigilância ou intervim directamente por meio de medidas opportunas. Prendem-se a esta sorte de providências as repetidas viagens dos delegados auxiliares e as muitas nomeações de autoridades militares para o interior, tendo recebido sempre, uns e outros, a incumbência de apaziguar exaltações, reprimir abusos, garantir o exercício de direitos, executar outras recommendações especiaes, a bem da ordem perturbada ou ameaçada, em localidades onde, por um ou outro motivo, se tornava conveniente a presença de autoridades extranhas ao meio" (Relatório da Secretaria da Justiça e da Segurança Pública, 1903, p. 490-494).

O destacado papel destinado à polícia no quadro judicial republicano também pode ser identificado nos dados orçamentários do governo paulista. Apesar do investimento nas forças policiais ter aumentado dentro do dispêndio geral da Secretaria da Justiça e da Segurança Pública, o montante relativo à Força Policial decresceu dentro do total do orçamento do Estado. Nos anos 1920, o Estado passou a gastar mais em instrução pública, em juros e amortizações e

juízes de direito, garantido pela lei” (Love, 1982, p. 175).

22 Bernardino Caropreso (1946), delegado de polícia na Primeira República, relata várias situações em que conflitos emergem nas atividades policiais e demonstra a relação complexa deles com o cotidiano do crime e da vida noturna, que muitas vezes encanta demasiadamente os policiais menos preparados a seguirem o caminho do "crime e do vício”. 
na modernização da estrada de ferro Sorocabana do que em força policiais. Não obstante, a partir da década de 1920, se processou uma gradual expansão da dotação orçamentária para a Polícia Civil estadual em relação à dotação destinada à Força Pública, tendência esta que se acentuou nos anos $1930 .^{23}$ Os dados disponíveis permitem inferir que, ao longo de 40 anos, o governo republicano gastou relativamente maior soma de recursos na polícia do que na justiça. Enquanto isso, a menor alocação de juízes de direito e de promotores públicos aumentou a morosidade e diminuiu a confiabilidade do processo formal e dos julgamentos; consequentemente, criou obstáculos para a proteção das garantias legais dos acusados. Esse processo refletiu-se na ineficiência do sistema de justiça criminal e na descrença popular na justiça. ${ }^{24}$

A República encontrou na pluralidade processual uma forma "legal” de reelaboração dos princípios do direito penal federal. A legislação penal e processual republicana implementou avanços inquestionáveis: aumentou as possibilidades de defesa dos acusados nos crimes comuns e restringiu as formas de prisão. No Estado de São Paulo, a oralidade do julgamento vigorava nos debates plenários diante do júri; entretanto, o processo escrito dominou todo o procedimento preliminar do inquérito policial ou de formação da culpa, com evidentes restrições do direito de defesa do acusado. Ou seja, o processo manteve-se com características de contraditório pleno no julgamento, mas restrito no sumário de culpa. E, muito embora a forma do processo ordinário fosse mantida tanto para os crimes inafiançáveis quanto afiançáveis, o inquérito policial, invenção obscura da Lei ${ }^{\circ} 2.033$, de 20 de setembro de 1871, que criou a Polícia Judiciária, continuou servindo como principal instrumento de promoção da denúncia ou da queixa, em todos os crimes comuns. O crime policial deixou de existir, o que pode induzir à errônea avaliação de que a ação da polícia teria sido limitada. A ação penal pública sofreu limitações assim como a própria ação da polícia,

${ }^{23}$ São Paulo sustentava a força policial mais cara do país, mas os paulistas podiam perfeitamente arcar com as despesas. Em termos reais (1912-100), os gastos com a Força Pública praticamente dobraram entre 1889-90 e 1900, com outro aumento superior a 50\% ocorrendo em 1910. Em termos absolutos (usando valores deflacionados), o máximo foi atingido em 1930. Entretanto, nos anos seguintes, ocorreu uma rápida elevação nos gastos com a política civil estadual (sic), corpo separado da Força Pública. Em 1936 e 1937, o governo investiu mais na polícia que na força (cf. Love: 1982: 177 e 354-355). Fato também observado por Heloísa Fernandes (1974, p. 247-248).

${ }^{24}$ Ao menos essas são as observações de Boris Fausto (1984) sobre a desproporção entre prisões, aberturas de inquéritos, processos e condenações durante a Primeira República e de Andrei Koerner sobre o caráter político das instituições do Poder Judiciário (1998). 
mas a introdução dos processos policiais permitiu que parcela considerável das infrações penais (sobretudo atitudes consideradas desordeiras ou suspeitas) provocasse a intervenção ex-officio da polícia. ${ }^{25}$ Essas intrincadas artimanhas processuais fizeram com que o artigo 407 do Código Penal fosse tacitamente derrogado, principalmente nos momentos em que a ordem pública ou o estado de sítio emergiam como substrato da ordem institucional republicana. ${ }^{26}$

\section{Polícia e o recorte da delinquência}

A comparação dos processos históricos das cidades de Manchester e São Paulo permite compreender a formação e as características das ordens legais subjacentes ao processo de industrialização. Manchester experimentou um notável crescimento em decorrência do boom industrial da Inglaterra e não pode dispor de uma administração pública organizada nem de recursos financeiros para investir em estrutura urbana ou em forças policiais. Ao contrário, a cidade de São Paulo, no auge da economia cafeeira, contou com crescente dotação orçamentária voltada para o melhoramento dos equipamentos urbanos e para a constituição de um aparato policial uniformizado e armado (milícia, guarda civil e polícia judiciária) preparado.

Embora Manchester tenha sua história marcada pelas manifestações populares e greves, condicionadas pela violência das condições de exploração do trabalho, no final do século XIX, os índices de repressão policial sobre os operários parecem diminuir. O poder público passa a ser visto como instituição que garante a ordem social e os direitos, ganhando portanto legitimidade frente ao operariado. A polícia especializa-se no trabalho criminal e surge a ideologia do policiamento baseado no consentimento, princípio presente no modelo atual de policiamento comunitário. Apesar do processo crescente de burocratização do poder público, a ação do Estado não se encaminhou na direção da negociação das demandas das classes trabalhadoras. Ao contrário, o movimento operário urbano foi reprimido e a maioria da população permane-

\footnotetext{
${ }^{25}$ João Francisco da Cruz (1932, p. 40), que exerceu a função de policial militar, de delegado e de processador de processo nos cursos de formação da Força Pública durante a Primeira República, remete constantemente a essa faculdade processual residual das autoridades policiais; Astolfo Rezende (1916, p. 420), que foi delegado especializado e chefe de polícia no Rio de Janeiro, critica veementemente o papel processual da polícia, alertando que o inquérito policial desviava a polícia da atividade de investigação.

${ }^{26}$ Este artigo (e o conjunto de seus parágrafos) regia as situações em que cabia a ação processual pública, segundo a qual a autoridade policial ou o Ministério Público deveriam proceder ao inquérito e/ou processo-crime sempre que tivessem notícia de que algum ato delitivo tivesse ocorrido (cf. Bastos, 1918).
} 
cia à margem das decisões governamentais. Ocorreu a reorientação da polícia de uma organização de baixa densidade burocrática, sem remuneração e que arregimentava seus homens nas fileiras mais baixas da sociedade para uma instituição fortemente organizada, com salários fixos e com critérios mais rígidos de recrutamento. Esta reorientação da polícia urbana também teve como alvo o controle da conduta pública da classe operária, mas principalmente esteve atrelada à demanda burocrática e social por maior controle sobre o crime e a delinquência. Nesse sentido, a polícia londrina, na primeira metade do século XIX, e as polícias das principais cidades americanas, na segunda metada do século XIX, passaram a receber fortes investimentos públicos voltados para a profissionalização de seus quadros, para a especialização de suas funções e para a constituição de uma trabalho criminal em detrimento muitas vezes da repressão ao movimento operário e de detenção do lúmpem-proletariado.

No caso da cidade de São Paulo e do Rio de Janeiro, ocorreu uma acentuada burocratização e especialização das funções policiais. Nesse sentido, de fato, os interesses privados deixaram de definir por completo a agenda pública, mas o equilíbrio sempre foi muito precário e dava margens a diversos problemas e hesitações no que diz respeito à aplicação da lei e à manutenção da ordem.

Em São Paulo, a milícia continha manifestações dos trabalhadores no meio urbano, a guarda civil provia o policiamento urbano cotidiano e a polícia civil especializava-se no combate ao crime contra o patrimônio. Essa última incorporou crescentemente em seus quadros e em suas práticas os novos padrões de controle da criminalidade, as novas aquisições da criminologia e da técnica policial. ${ }^{27}$ As informações policiais circulavam em congressos e em publicações especializadas; policiais e juristas brasileiros estavam em permanente contato com as novidades e as traduziam para o contexto local. As principais mudanças no padrão organizacional das polícias foram fruto da nova consciência das elites políticas e institucionais diante dos desafios da sociedade urbana e industrial, das pressões sociais em favor do combate ao crime e à criminalidade, da voracidade estatal e das demandas corporativas das elites de bacharéis de direito. Uma das principais bandeiras da reforma dizia respeito à exigência da formação em direito para a ocupação de cargos na estrutura da polícia civil, a começar pelo cargo de

\footnotetext{
${ }^{27}$ Para uma análise elucidativa da importância da criminologia no contexto das reformas institucionais republicanas, ver ALVAREZ, Marcos César. Apontamentos para uma história da criminologia no Brasil. In: KOERNER, Andrei (org.). História da justiça penal no Brasil. Pesquisas e análises. São Paulo: Ibccrim, 2006.
} 
delegado, com a definição subsequente de uma carreira policial. Rapidamente, o cenário profissional alterou-se dos delegados leigos, colocados no cargo por algum alvitre político, para profissionais que pretendiam seguir carreira nos quadros da burocracia policial e assim sentiam-se à vontade com o trabalho criminal e com as diligências policiais. A burocratização, inclusive, foi responsável pela maior exigência de profissionalização, o que obrigou à criação de uma hierarquia policial rígida e delegacias especializadas. Os delegados de polícia dos distritos policiais ou das comarcas do interior tinham que lidar com casos de pequena importância e tinham sob sua responsabilidade um pequeno número de pessoal: carcereiro, escrivão e destacamento de praças da Força Pública. Os delegados especializados podiam contar com uma estrutura de poder mais arrojada, o que aumentava seu apetite por crescimento na carreira e por reconhecimento político de suas ações. Se a polícia recebeu investimentos materiais, humanos e técnicos crescentes, ela continuava a ser um aparelho cujo domínio pertencia a um pequeno grupo social, constituindo um verdadeiro mandarinato, muitas vezes com pretensões políticas. Assim, a carreira policial e a especialização da polícia na prevenção e na repressão ao crime ainda esbarravam nas urgências políticas voltadas para o controle popular e para a acomodação de interesses no interior dos conflitos interelites. ${ }^{28}$

O processo de reformulação das instituições policiais brasileiras, nos primórdios da República, criou condições institucionais de profissionalização da polícia, ao mesmo tempo em que implementou um sistema de vigilância e de punição voltado essencialmente para as camadas populares da população. ${ }^{29}$ No Brasil, os problemas eram estruturais e se relacionavam a uma sociedade que sempre relutou em reconhecer direitos. Creio que uma análise detida da literatura especializada permitiria avaliar melhor as características particulares de cada sociedade, a formação e a atuação dos seus aparelhos de segurança. A Polícia Civil, no caso específico de São Paulo, enquanto instituição que administra conflitos numa ordem social ainda hierarquizada, não podia estar isenta dos dilemas que atravessavam a sociedade, e o caráter arbitrário e particularista das suas ações permaneceu inalterado em seus princípios fundamentalmente patrimoniais.

\footnotetext{
${ }^{28}$ Mesmo durante o período pós-Estado Novo, essas grandes linhas da instituição policial e da segurança pública parecem que ficaram razoavelmente inalteradas. BATTIBUGLI, Thaís. Segurança pública e cultura policial paulista 1945-1964. In: KOERNER, Andrei (org.). História da justiça penal no Brasil. Pesquisas e análises. São Paulo: Ibccrim, 2006.

${ }^{29}$ A regularização dos mecanismos de punição articula-se "diretamente com a exigência de submeter a ilegalidade popular a um controle mais estrito e mais constante” (Foucault, 1987, p. 81).
} 
Para pensar a persistência do arbítrio e da violência nas ações das polícias no Brasil talvez devêssemos considerar duas ordens de discussões: em primeiro lugar, a manutenção de um padrão de ocupação do Estado que ainda tem características patrimoniais, Estado instrumentalizado pelas elites políticas, econômicas e institucionais como forma de manter as hierarquias sociais e colocar cada indivíduo em seu respectivo lugar, não obstante a incorporação das regras da cidadania no quadro jurídico mais amplo. Em segundo, um amplo processo de especificação do crime e de criminalização dos comportamentos populares. Esse processo corre paralelo com o não-reconhecimento dos direitos civis e sociais dos pobres urbanos. À polícia, dentro dos projetos institucionais republicanos, reservou-se papel relevante tanto no que diz respeito à privatização dos espaços públicos como na criminalização dos trabalhadores livres.

\section{Conclusão}

A formação das instituições republicanas no Brasil a par da legislação que confirmava os preceitos da universalidade da lei, das garantias individuais e da igualdade jurídica, peças básicas para a implementação da cidadania, não confirmou o quadro de um Estado voltado para o ideal de nação, no qual houvesse a rígida separação entre a personalidade jurídica e pública e a pessoa física e privada. Ao contrário, todo o arcabouço legal e institucional republicano foi gestado de modo a manter as práticas básicas de um Estado que não faz distinções entre domínios públicos e interesses privados. A relação entre práticas patrimoniais e ação policial permite observar as estratégias da constituição da ordem pública (com ênfase na segurança das elites e de seus patrimônios) em detrimento de uma esfera pública (a segurança social mais ampla e as franquias públicas). O Estado democrático moderno privilegia atitudes autorreguladas, a publicização das ações do Estado consoante à definição dos negócios eminentemente de interesse público, a universalização da lei e dos contratos e, sobretudo, a formação de uma opinião pública, a partir da qual os atos governamentais podem ser fiscalizados. O Estado brasileiro assenta-se contraditoriamente nos princípios da democracia e da desigualdade social, em que os direitos são restritos em prol de interesses privados, a universalidade da norma esbarra nas vantagens e na posição pessoais. A polícia, em seu processo complexo de constituição, alimenta a, e se alimenta dessa contradição. Além da cultura jurídica implicitamente elitista e da especialização das atividades policiais no que diz respeito à construção do delinquente, subsiste, na prática policial, um grande nível de discricionaridade que somente pode ser 
entendida a partir do quadro mais amplo da permanência do patrimonialismo. A prática policial, embebida em diferentes teorias acerca das origens do crime e do criminoso, secreta um conjunto de percepções e valorações que insidiosamente impregna a sociedade inteira. $\mathrm{O}$ choque provocado pelo contato entre autoridades policiais e os chamados delinquentes produz discursos eficazes no que diz respeito às necessidades de contenção do criminoso, de violação de direitos e de aumento do rigor da punição, como forma de manutenção da segurança pública.

\section{Referências bibliográficas}

ABREU, Sérgio Adorno F. de. Os aprendizes do poder. O bacharelismo liberal na política brasileira. Rio de Janeiro: Paz e Terra. 1988.

ALVAREZ, Marcos César. Bacharéis, criminologistas e juristas. Saber jurídico e nova escola penal no Brasil. São Paulo: Ibccrim, 2003.

ALVAREZ, Marcos César. Apontamentos para uma história da criminologia no Brasil. In: KOERNER, Andrei (org.). História da justiça penal no Brasil. Pesquisas e análises. São Paulo: Ibccrim, 2006.

BATTIBUGLI, Thaís. Segurança pública e cultura policial paulista 1945-1964. In: KOERNER, Andrei (org.). História da justiça penal no Brasil. Pesquisas e análises. São Paulo: Ibccrim, 2006.

BASTOS, José Tavares. Código Penal brasileiro comentado e acrescido de jurisprudência. São Paulo: Cia Teixeira \& C. Editores, 1918.

BRETAS, Marcos Luiz. A guerra das ruas. Povo e polícia na cidade do Rio de Janeiro. Rio de Janeiro: Arquivo Nacional, 1997.

BRETAS, Marcos Luiz. Ordem na cidade. O exercício cotidiano da autoridade policial no Rio de Janeiro (1907-1930). Rio de Janeiro: Rocco, 1997.

CANCELLI, Elizabeth. O mundo da violência: a polícia na era Vargas. $2^{\mathrm{a}}$ ed. Brasília: Editora Universidade de Brasília, 1994.

CARONE, Edgard. A Primeira República, texto e contexto. São Paulo: Difusão Europeia do Livro, 1973.

CAROPRESO, Bernardino. Quatro lustros de polícia. São Paulo: sem editora, 1946.

CARVALHO, José Murilo de. A construção da ordem. A elite política imperial. Brasília: Edunb, 1981. Coleção Temas Brasileiros, vol. 4.

CARVALHO, José Murilo de. Os bestializados. O Rio de Janeiro e a República que não foi. São Paulo: Cia. das Letras, 1991.

CHALHOUB, Sidney. Trabalho, lar e botequim. O cotidiano dos trabalhadores no Rio de Janeiro da bélle époque. São Paulo: Brasiliense, 1986.

CRUZ, João Francisco da. Tratado de polícia. São Paulo: Revista dos Tribunais, 1932. 
CUNHA, Maria Clementina Pereira da. O espelho do mundo. Juquery, a história de um asilo. Rio de Janeiro: Paz e Terra, 1986.

FAORO, Raymundo. Os donos do poder. Formação do patronato político brasileiro. $8^{\mathrm{a}}$ edição. 2 vols. Rio de Janeiro: Globo, 1989.

FARIA, Júlio Cesar de. Juízes do meu tempo. São Paulo: Martins Editora, 1942.

FAUSTO, Boris. Crime e cotidiano. A criminalidade em São Paulo, 1880-1924. São Paulo: Brasiliense, 1984.

FAUSTO, Boris. Trabalho urbano e conflito social. 1890-1920. São Paulo: Difel, 1977.

FERNANDES, Heloísa. Política e segurança. História da Força Pública de São Paulo. São Paulo: Alfa-Omega, 1974.

FONSECA, Luiz. Washington Luis Pereira de Sousa (1897-1920): o administrador, o político, o homem. São Paulo: Pocai \& Comp, 1920.

FOUCAULT, Michel. Sobre a prisão. In: Microfísica do poder. $5^{a}$. edição. Rio de Janeiro: Graal, 1985.

FOUCAULT, Michel. Vigiar e punir. História da violência nas prisões. $5^{\text {a }}$ edição. Petrópolis: Vozes, 1987.

FRANCESCO, Braz di. Pela cultura policial. São Paulo: Casa Duprat, 1931.

FRANCO, Maria Sylvia de Carvalho. Homens livres na ordem escravocrata. 3. edição. São Paulo: Kairós, 1983.

FRY, Peter e CARRARA, Sérgio. As vicissitudes do liberalismo no direito penal brasileiro. Revista Brasileira de Ciências Sociais, 2 (1), 1986.

HOLLOWAY, Thomas. Polícia no Rio de Janeiro. Repressão e resistência numa cidade do século XIX. Rio de Janeiro: FGV, 1997.

KOERNER, Andrei. Judiciário e cidadania na construção da República brasileira. São Paulo: Hucitec, 1998.

KOERNER, Andrei (org.). História da justiça penal no Brasil. Pesquisas e análises. São Paulo: Ibccrim, 2006.

LEAL, Victor Nunes. Coronelismo, enxada e voto. O município e o regime representativo no Brasil. $2^{\mathrm{a}}$ edição. São Paulo: Alfa-Ômega, 1975.

LIMA, Roberto Kant de. Cultura jurídica e práticas policiais: a tradição inquisitorial. Revista Brasileira de Ciências Sociais, 10 (04), 1989.

LOVE, Joseph. A locomotiva. São Paulo na federação brasileira. 1889-1937. Rio de Janeiro: Paz e Terra, 1982.

MAUCH, Cláudia. Ordem pública e moralidade. Imprensa e policiamento urbano em Porto Alegre na década de 1890. Santa Cruz do Sul: Edunisc, 2004.

MONKKONEN, Eric H. Police in urban America. 1860-1920. Cambridge: Cambridge University Press, 1981. 
PAIXÃO, Antonio Luiz. Crime, controle social e consolidação da democracia. In: REIS, Fábio Wanderley. \& O'DONNELL, Guillermo. A democracia no Brasil. Dilemas e perspectivas. São Paulo: Vértice, 1988.

PEIXOTO, Afrânio. Criminologia. São Paulo: Cia. Editora Nacional, 1933.

PINTO, Maria Inez Machado Borges. Cotidiano e sobrevivência. A vida do trabalhador pobre na cidade de São Paulo. São Paulo: Edusp, 1994.

QUEIROLO, Sylvia. O espaço conceitual da periculosidade. Direito penal e criminologia. Dissertação de Mestrado, Fadusp, 1984.

RAGO, Luiza Margareth. Do cabaré ao lar. A utopia da cidade disciplinar. Rio de Janeiro: Paz e Terra, 1985.

REZENDE, Astolfo. Polícia administrativa, polícia judiciária. Revista do Instituto Histórico e Geográfico Brasileiro, volume especial dedicado ao I Congresso Brasileiro de História, 1916.

ROSEMBERG, André. Ordem e burla. Processos sociais, escravidão e justiça em Santos. São Paulo: Alameda, 2006.

ROSEMBERG, André. Polícia, policiamento e o policial na província de São Paulo no final do Império. Tese de Doutorado, FFLCH-USP, 2008.

SALLA, Fernando. As prisões em São Paulo, 1822-1940. São Paulo: Annablume, 1999.

SCHWARTZMAN, Simon. São Paulo e o Estado nacional. São Paulo: Difel, 1975.

SOARES JR., Rodrigo. Jorge Tibiriçá e sua época. São Paulo: Companhia Editora Nacional, 1958. Coleção Brasiliana, 304. 2 vols.

SOUZA, Luís A. F. Polícia, poder de polícia e criminalidade numa perspectiva histórica. In: KOERNER, Andrei (org.). História da justiça penal no Brasil. Pesquisas e análises. São Paulo: Ibccrim, 2006.

SOUZA, Luís A. F. Polícia, violência e patrimonialismo em São Paulo (1889-1930). In: Métis. História \& Cultura. Revista de História da Universidade de Caxias do Sul, v. 6, n. 11, jan/jun 2007.

THOMPSON, E. P. The moral economy of the English crowd in the eighteenth century. In: Customs in commom. Studies in traditional popular culture. New York: The New Press, 1993.

VELLASCO, Ivan de Andrade. As seduções da ordem. Violência, criminalidade e administração da justiça. Minas Gerais, século XIX. São Paulo: Edusc, 2004.

Recebido: fevereiro/2009 - Aprovado: setembro/2009. 